\title{
AN ANALYSIS OF THE POSSIBILITY OF INTERSYSTEM TRANSFORMATIONS FOR PURPOSES OF GEO-REFERENCING OLD MINE WORKINGS
}

\section{ANALÝZA MOŽNOSTI MEZISYSTÉMOVÝCH TRANSFORMACÍ PRO ÚČELY GEOREFERENCOVÁNÍ STARÝCH DŮLNÍCH DĚL}

\author{
Hana STAŇKOVÁ ${ }^{1}$, Pavel ČERNOTA ${ }^{2}$, Miroslav NOVOSAD ${ }^{3}$
}

\author{
${ }^{1}$ Ing. Ph.D., Institute of Geodesy and Mine Surveying, Faculty of Mining and Geology, \\ VSB-Technical University of Ostrava, 17. listopadu 15, 70833 Ostrava - Poruba, Czech Republic \\ e-mail:hana.stankova@vsb.cz \\ ${ }^{2}$ Ing. Ph.D., Institute of Geodesy and Mine Surveying, Faculty of Mining and Geology, \\ VSB-Technical University of Ostrava, 17. listopadu 15, 70833 Ostrava - Poruba, Czech Republic \\ e-mail: pavel.cernota@vsb.cz \\ ${ }^{3}$ Ing. Ph.D., Institute of Geodesy and Mine Surveying, Faculty of Mining and Geology, \\ VSB-Technical University of Ostrava, 17. listopadu 15, 70833 Ostrava-Poruba, Czech Republic \\ e-mail: miroslav.novosad@vsb.cz
}

\begin{abstract}
The paper is dedicated to the issues of both planar and spatial transformations with respect to the territory affected by mining activities. The planar transformations have been applied among the planar Otto mine coordinate system, St. Stephen Datum of Cadastre Coordinates, and the Datum of Uniform Trigonometric Cadastral Network (hereinafter referred to as JTSK). Here basic transformation characteristics among the above systems are defined. The spatial transformation is performed through a point coordinate conversion between the JTSK and the European Terrestrial Reference System (hereinafter referred to as ETRS89) where conventional relations as well as other conversion possibilities were described. Part of the article is the execution of an experiment of a direct transformation between the St. Stephen Datum of Cadastre Coordinates and the ETRS98 system for the territory of Brno, which was not affected by mining activities. For the above transformation, 8 trigonometric points were used, for which the identity analysis had been done initially. Furthermore, the Interpolation and One Step Transformations were tested, which solve the conversion as divided tasks for both position and heights. The Interpolation Transformation showed better values for residues. The results of the above experiment will be applied for purposes of surveying old mine workings using the GNSS technology.
\end{abstract}

\begin{abstract}
Článek je věnován problematice rovinných a prostorových transformací s ohledem na území ovlivněném hornickou činností. Rovinné transformace byly aplikovány mezi rovinným Ottovým dủlním souřadnicovým systémem, Katastrálním souřadnicovým systémem svatoštěpánským a systémem Jednotné trigonometrické sítě katastrální (JTSK). Zde jsou definovány základní charakteristiky převodu mezi těmito systémy. Prostorová transformace je realizována převodem souřadnic bodů mezi systémem JTSK a Evropským terestrickým referenčním systémem (ETRS89), kde jsou popsány konvenční vztahy a další možnosti převodu. Součástí článku je realizace experimentu přímé transformaci mezi katastrálním souřadnicovým systémem svatoštěpánským a systémem ETRS98 na území Brna, které není hornickou činností ovlivněno. Pro tuto transformaci bylo použito 8 trigonometrických bodů, u nichž byla původně provedena analýza identity. Testována byla Interpolační transformace a transformace One Step, které řeší převod jako rozdělené úlohy pro polohu a pro výšky. Lepší hodnoty reziduí vykazovala Interpolační transformace. Výsledky experimentu budou použity pro účely vytyčení starých důlních děl technologií GNSS.
\end{abstract}

Key words: geo-referencing, St. Stephen Datum of Cadastre Coordinates, ETRS89, coordinate transformation, Datum of Uniform Trigonometric Cadastral Network, abandoned working 


\section{INTRODUCTION}

The issues of determining positions of old mine workings in the territory of cancelled mining areas in the western part of the Ostrava-Karvina Coalfield (OKC) is still a current problem. Abandoned old main mine workings from the 19th century, imperceptible in the landscape, became, after the backfilling of active pit shafts in connection with the termination of mining in the 90ies of the 20th century, a natural collector of methane exhalations from underground to the surface. So they become a security risk to human health and environment. Old mine workings, abandoned exploratory workings, abandoned mine workings and other objects are distinguished. An old mine working is understood to be an underground mine or quarry, whose original operator or its successor is unknown. Abandoned exploratory workings operated through state resources within geological survey, which were not passed for exploitation after the work completion. Abandoned mine workings are the workings out of operation, which have their owner or successor. Other objects are subsurface areas, which have been excluded for a purpose other than for mining and exploring mineral resources.

In the process of elimination of consequences of coal mining, it was necessary to find and cleanup old main mine workings and pits whose position had been originally determined in the Otto Coordinate System. The Otto District Coordinate System in the OKC was introduced in the mid-19th century by Ing. Francis Otto, the main mining surveyor of the Ferdinand's track. Positions of all significant points of in-those-days existing adits and pits, characteristic points of the terrain and other monumented points on the surface, were determined from a performed triangulation. The relation between the Otto Coordinate System and the St. Stephen Datum of Cadastre Coordinates is given by a linear transformation.

However, for the needs of state and local governments for planning and developing land affected by coal exploitation, it is necessary to convert (transform) the coordinates of positions of main mine workings and original pits from the 19th century to the coordinates of binding reference systems of the Czech Republic. The conversions between the systems are solved by transformations that can be performed in different ways with different results. The transformation type selection depends on required accuracy and the need to maintain the correct size of network.

An established way of converting point coordinates from the St. Stephen Datum of Cadastre Coordinates to the ETRS89 system is the transformation through S-JTSK. An experiment was carried out in Brno and its environs, consisted in a direct transformation between the St. Stephen Datum of Cadastre Coordinates and ETRS89 without a transition via the JTSK system. As identical points, the points of stable cadastre geodetic base were used, i.e. the points of cadastral triangulation (1822-1829) of order I, II and III.

\section{TRANSFORMATIONS BETWEEN COORDINATE SYSTEMS}

A transformation is generally understood to be a method of changing trigonometric coordinates or coordinates of other positional points - individually or collectively, for a given area, in fact without changing positions of points on the physical Earth's surface.

The main reasons for performing a transformation are according to [5] as follows:

1. Choice of a different reference ellipsoid when geographical point coordinates are being changed - to the same length of the trigonometric side different coordinate differences $(\Delta \varphi, \Delta \lambda)$ correspond.

2. Shift, angular displacement or scale change in the entire network of permanently marked points when the scale specification, change in orientation or network approach to surrounding networks occur.

3. Change in the method for projecting an ellipsoid into a plane. The geographic coordinates of the point $(\varphi, \lambda)$ remain the same, but can be transformed into a plane of e.g. conical or cylindrical projection. Therefore, it is a direct transformation $(x, y) \Rightarrow(X, Y)$ without an intermediate transition via the geographic coordinates, where $\mathrm{x}, \mathrm{y}$ are the coordinates of the original (old) coordinate system and $\mathrm{X}, \mathrm{Y}$ of the new one.

4. New surveying a part of the network. This includes a new triangulation (formerly), then new distance measurement, and currently measurements by means of GNSS (Global Navigation Satellite System).

5. The transition to new coordinate systems (geodetic system). This is a new measurement, new processing. 
The first three cases above concerns a transformation of homogeneous coordinates. During this transformation, angle values remain constant and between the original (primary) and new (secondary) systems, precise mathematical relations apply. Cases 4 and 5 concern a transformation of non-homogeneous coordinates, when values of angles and lengths are randomly being changed, and there is no exact mathematical relation for converting coordinates from one system to another.

It is possible to transform coordinates not only of real, i.e. monumented points, but also of lost or notional points (e.g. corners of map sheets). The first step in a transformation is setting up a key of transformation, whose form depends on the applied transformation method and the selection of identical points. Identical points are such points, for which coordinates are known in both the original and new systems. If a necessary number of identical points are available, the calculation of other point coordinates is executed directly by means of a simple key of transformation.

The choice of identical points is crucial [13]. In order to maintain homogeneity and for possible shifts in certain point stabilisation, it is convenient to relate densification points (non-identical) to the given (identical) points so that they lie inside the polygon circumscribed by marginal identical points of the densified (transformed) area. Worse homogeneity may occur, for example, when relating the determined points only to one or two identical points. For assessing the quality of inserting new networks into original ones, or vice versa, in particular scale conversions, angular rotations and position deviations of identical points may be useful.

The number of identical points is usually higher than necessary, so to calculate adjusted coefficients of a key of transformation, a least squares adjustment method is used. Such transformed point coordinates of a new system, are burdened by residual deviations arising from differences between the given and transformed point coordinates. These deviations have the same value as coordinate corrections, but with an opposite sign. In order to avoid the lack of homogeneity (deformation) of a whole minor control towards identical points, it is vital to introduce corrections also in case of other detailed survey points. Among a number of methods permitting a classification of coordinate corrections there are:

- Graphic method (plotting a chart of corrections);

- Method of a general arithmetic mean of an identical point shift - Jung's transformation;

- Spline interpolation [23].

\section{PLANAR TRANSFORMATION BETWEEN S-OTT, S-SK (ST. STEPHEN DATUM, GUSTERBERG DATUM) AND S-JTSK}

The X-axis of Otto Coordinate System was parallel to the X-axis of the stable cadastre coordinate system passing through the main tower of St. Stephen's Cathedral in Vienna. This cadastral system was valid for the countries of the Austro-Hungarian Empire, Lower Austria, Moravia, Silesia and Dalmatia. The relation between the Otto Coordinate System and the St. Stephen Datum of Cadastre Coordinates is given by the following linear transformation:

$$
\begin{aligned}
& y=y_{0}+Y^{\prime} \cos \psi+X^{\prime} \sin \psi, \\
& x=x_{0}+X^{\prime} \cos \psi-Y^{\prime} \sin \psi,
\end{aligned}
$$

where $\mathrm{y}_{0}=-138443.332 \mathrm{~m}, \mathrm{x}_{0}=-183579.651 \mathrm{~m}$ are the coordinates of the Otto system origin in S-SK; $\mathrm{Y}^{\prime}$, $\mathrm{X}^{\prime}$ are the coordinates in St. Stephen Datum of Cadastre Coordinates; and $\psi=180^{\circ}$ is the angle of the meridian of the Otto Coordinate System against the meridian of the St. Stephen Datum of Cadastre Coordinates.

Connecting the Otto triangulation to the St. Stephen Datum of Cadastre Coordinates was solved by measuring the points of cadastral triangulation of order II in the "Ostrava Region". It concerned churches (church towers) in municipalities Vratimov (Ratimow), Hoštákovice (Hostialkowitz) and Vrbice (Wirbitz). More information about the St. Stephen Datum of Cadastre Coordinates may be found in [22] and [23].

According to [1], the derivation of a genuine link between the systems S-SK (stable cadastre coordinate system) and S-JTSK encounters certain below mentioned drawbacks.

1. An error occurred in the determination of the Gusterberg datum direction as the $X$-axis does not identify with the Gusterberg point meridian, but forms a small angle (4'22.3') westwards. The original cadastral maps of Bohemia are thus oriented according to a different meridian [20].

2. In [2], it is stated that there is no established transition method from an ellipsoid to a reference surface or a reduction of bearings into a plane. A reduction of bearings into a plane is described 
e.g. in [4], but it is not documented whether this reduction was introduced or not. Horizontal angles in triangles were corrected only by a spherical excess (in order I only) and the calculation was carried out as in planar nets.

3. The net was constructed according to the needs of detailed measuring, therefore the procedure from large to small was not observed.

4. The conversion coefficient value to convert from fathom to metric system is not identical in different literature sources. The coefficient value was identified in UAZK archive materials (Central Archives of Surveying, Mapping and Cadastre) and one value was always found out $1^{\circ}=1,896483843 \mathrm{~m}$. This value corresponds e.g. to the data in [19] and [3].

5. It is possible to meet different values of coordinate system origins, whether in the Gusterberg Datum or St. Stephen Datum.

6. The variability of scales of both projections $\mathbf{Q}=\mathbf{M}_{\mathbf{j t s k}}: \mathbf{M}_{\mathbf{s k}}$ causes that the direct point series of one system is transformed into the other system as a curve. This is most manifested in straight lines parallel to isometric lines $q=$ const. In perpendicular sides, straight line retention applies, however with a maximum failure of dividing ratio.

\section{SPATIAL TRANSFORMATION BETWEEN S-JTSK AND ETRS89 SYSTEMS}

Coordinates obtained from measuring using the GNSS technology in the ETRS89 system may be transformed into S-JTSK in the following ways [6], [7], [15].

1. Through transformations of rectangular coordinates of $\mathrm{X}, \mathrm{Y}, \mathrm{Z}$ in the ETRS89 to rectangular coordinates of the Bessel ellipsoid by means of: spatial identity transformation; spatial similarity transformation; general k-th degree polynomial transformation and a follow-up conversion of the transformed rectangular coordinates to geographic coordinates with a further conversion into a S-JTSK plane.

2. Converting rectangular coordinates of $\mathrm{X}, \mathrm{Y}, \mathrm{Z}$ in the ETRS89 system to geographic coordinates of the Bessel ellipsoid, followed by a cartographic conversion into a S-JTSK plane and through a planar similarity transformation of $\mathrm{Y}, \mathrm{X}$ coordinates in a Krovak's projection with an additional height transformation.

3. Converting plane coordinates of $\mathrm{Y}, \mathrm{X}$ and height $h$ of identical points from the JTSK system to the Bessel ellipsoid, followed by an identity transformation to the centric Bessel ellipsoid, adjusting GNSS vectors on this ellipsoid with identical points as fixed ones and an inverse identity transformation of all the points back to the Bessel ellipsoid, finally classically converting into S-JTSK.

4. Through the reduction of the measured vectors using the GNSS technology to the Bessel ellipsoid, conversion to S-JTSK and classical adjustment as in terrestrial measuring.

5. Through an interpolation method without the knowledge of map projection or relevant reference ellipsoid dimensions. The ground of the solution is the identification of a projection relation between identical point coordinates.

\section{4,1 Similarity transformation}

The similarity (Helmert) transformation is used to convert geodetic networks, which approximately are of the same shape in both coordinate systems, but differ in size. The most commonly used spatial transformation is the one with the following parameters:

- $\Delta X, \Delta Y, \Delta Z$ are the coordinate differences reflecting a shift of the Bessel ellipsoid towards the GRS80 ellipsoid,

- $\alpha, \beta, \gamma$ are the angles expressing the angular displacement of the transformed system relative to the coordinate axes,

- $\Delta m$ is the scale factor.

For that transformation two mathematical models are used as follows:

- Bursa - Wolf Model (3), 
- Molodensky - Badekas Model (4).

The first (Bursa - Wolf) model solves the searched parameters in regard to the geocentre and is therefore suitable for transformations of larger networks. The latter (Molodensky - Badekas) model uses the coordinates of the centre of gravity of identical points instead of the geocentre and is suitable for smaller areas to be transformed.

\section{Bursa-Wolf Model}

$$
\left(\begin{array}{l}
X_{i} \\
Y_{i} \\
Z_{i}
\end{array}\right)_{\text {Bess }}=\left(\begin{array}{l}
\Delta X \\
\Delta Y \\
\Delta Z
\end{array}\right)_{\text {Bess }}+(1+\Delta m) \cdot\left(\begin{array}{ccc}
1 & \gamma & -\beta \\
-\gamma & 1 & \alpha \\
\beta & -\alpha & 1
\end{array}\right) \cdot\left(\begin{array}{l}
X_{i} \\
Y_{i} \\
Z_{i}
\end{array}\right)_{\text {ETRS } 89}
$$

Molodensky - Badekas Model

$$
\left(\begin{array}{c}
X_{i} \\
Y_{i} \\
Z_{i}
\end{array}\right)_{\text {Bess }}=\left(\begin{array}{c}
\bar{X}_{t} \\
\bar{Y}_{t} \\
\bar{Z}_{t}
\end{array}\right)_{\text {Bess }}+(1+\Delta m) \cdot\left(\begin{array}{ccc}
1 & \gamma & -\beta \\
-\gamma & 1 & \alpha \\
\beta & -\alpha & 1
\end{array}\right) \cdot\left(\begin{array}{c}
X_{i}-X_{t} \\
Y_{i}-Y_{t} \\
Z_{i}-Z_{t}
\end{array}\right)_{\text {ETRS } 89}
$$

$\bar{X}_{t}, \bar{Y}_{t}, \bar{Z}_{t}$ are the gravity centre coordinates of identical points in JTSK,

$X_{t}, Y_{t}, Z_{t}$ are the gravity centre coordinates of identical points in ETRS89,

$X_{i}, Y_{i}, Z_{i}$ are the coordinates of the points to be transformed.

In both models, the rotation matrix is simplified due to small values of angles of rotation. After performing the spatial transformation of ETRS89 coordinates to the Bessel ellipsoid and cartographic conversion into S-JTSK, the completion of transformation of coordinates $\mathrm{Y}, \mathrm{X}$ is used [17].

The transformation schema according to [16] which represents a 7-element Helmert similarity transformation of spatial coordinates with a subsequent transformation completion that already takes place in a plane of the Krovak projection.

\section{Transformation $\left(B, L, H_{\text {el. }}\right)$ in ETRS-89 to $\left(Y, X, h_{N}\right)$ in S-JTSK :}

$\left(\mathrm{B}, \mathrm{L}, \mathrm{H}_{\mathrm{el}}\right)_{\text {geoc. }} \Rightarrow\left(\mathbb{1} \Rightarrow(\mathrm{X}, \mathrm{Y}, \mathrm{Z})_{\text {geoc. }} \Rightarrow(2) \Rightarrow(\mathrm{X}, \mathrm{Y}, \mathrm{Z})_{\text {Bessel }} \Rightarrow(3) \Rightarrow\left(\mathrm{B}, \mathrm{L}, \mathrm{H}_{\mathrm{N}}\right)_{\text {Bessel }} \Rightarrow(4) \Rightarrow(\mathrm{Y}, \mathrm{X})_{\mathrm{Krovak}}\right.$

$\left(\mathrm{H}_{\mathrm{el} .}\right) \Rightarrow(5) \Rightarrow\left(\mathrm{H}_{\mathrm{N}}\right)$

(1) transfer of ellipsoidal coordinates to spatial rectangular ones (introduction of quasi-geoid height)

(2) seven-element Helmert Spatial Transformation,

(3) inverse to (1),

(4) equations of the Krovak projection with addition of corrections $(\Delta \mathrm{X}, \Delta \mathrm{Y})$,

(5) simple adding the height of quasi-geoid. In (1) and (4), $\mathrm{H}_{\mathrm{el}}$. plays only a mediating role.

Transformation $\left(Y, X, H_{N}\right)$ in S-JTSK to $\left(B, L, H_{\text {el. }}\right)$ in ETRS-89:

$(\mathrm{Y}, \mathrm{X})_{\mathrm{Krovak}} \Rightarrow 4^{\prime} \Rightarrow\left(\mathrm{B}, \mathrm{L}, \mathrm{H}_{\mathrm{N}}\right)_{\text {Bessel }} \Rightarrow(3)^{\prime} \Rightarrow(\mathrm{X}, \mathrm{Y}, \mathrm{Z})_{\text {Bessel }} \Rightarrow$ (2) $\Rightarrow(\mathrm{X}, \mathrm{Y}, \mathrm{Z})_{\text {geoc. }} \Rightarrow\left(1^{\prime} \Rightarrow\left(\mathrm{B}, \mathrm{L}, \mathrm{H}_{\mathrm{el}}\right)_{\text {geoc. }}\right.$

$\left(\mathrm{H}_{\mathrm{N}}\right) \Rightarrow(5)^{\prime} \Rightarrow\left(\mathrm{H}_{\mathrm{el}}\right)$

Dashed transformations are inverse transformations to non-dashed ones.

\subsection{Identity transformation}

The identity transformation is used if a network shape has been changed in a new position and the transformed points should better comply with the given identical points. The objective of an identity transformation is to adjust the shape and dimensions of a pattern formed by points in one system to the shape and dimensions of a point pattern in the other system.

The transformation key includes the following parameters:

- $\Delta X, \Delta Y, \Delta Z$ are coordinate differences which express a Bessel ellipsoid shift to a GRS80 ellipsoid;

- $\alpha, \beta, \gamma$ are angles expressing the transformed system rotation with respect to coordinate axes. 


$$
\left(\begin{array}{l}
X_{i} \\
Y_{i} \\
Z_{i}
\end{array}\right)_{\text {Bess }}=\left(\begin{array}{l}
\Delta X \\
\Delta Y \\
\Delta Z
\end{array}\right)_{\text {Bess }}+\left(\begin{array}{ccc}
1 & \gamma & -\beta \\
-\gamma & 1 & \alpha \\
\beta & -\alpha & 1
\end{array}\right) \cdot\left(\begin{array}{c}
X_{i} \\
Y_{i} \\
Z_{i}
\end{array}\right)_{\text {ETRS } 89}
$$

The transformation key does not include any coordinate scale change.

\title{
4.3 General polynomial transformation
}

This method of transformation may be used for the transformation of point position as well as for transformations of heights. Its principle is an interlay of a k-th degree planar polynomial function with identical points [18].

The transformation relation of B,L geographic coordinates is as follows:

$$
\begin{aligned}
& B_{\text {Bess }}-B_{\text {ETRS 890 }}=\Delta B=\sum_{i=0}^{k} \sum_{j=0}^{i} a_{i-j, j} \cdot U^{i-j} \cdot V^{j} \\
& L_{\text {Bess }}-L_{\text {ETRS 890 }}=\Delta L=\sum_{i=0}^{k} \sum_{j=0}^{i} b_{i-j, j} \cdot U^{i-j} \cdot V^{j},
\end{aligned}
$$

where: $\quad B, L,-$ parameters of geographic coordinates,

$a, b$, - searched transformation parameters,

$U, V$ - reduced geographic coordinates in ETRS89,

$U=p\left(B-B_{0}\right), V=p\left(L-L_{0}\right), p=c \pi / 180$,

$B_{o}, L_{o}-$ selected reduction values,

$c$ - $\quad$ selected constant (reduced coordinates should be in the interval of $\langle-1,1\rangle$ ),

$k$ - $\quad$ index of general transformation degree, and

$i, j$ - $\quad$ integer indices with a condition $i-j \cap j \leq 9$ limiting individual member powers

Increasing the number of polynomial function degrees, the planar polynomial more approaches all the identical points and thus it is possible to obtain lower values of transformation key accuracy characteristics. Using a sufficient number of quality identical points and their balanced distribution it is possible to give a true picture of a local network deformation via a polynomial function. This transformation between ETRS89 and S42/83 was used for the whole Czech Republic.

\subsection{Other methods of converting local planar systems into geocentric ones}

\author{
Conformal transformation of higher orders
}

This transformation respects angles to avoid a new network shape disruption. Its application is exceptional, e.g., when inserting a more accurate network into an older, less accurate basis. The transformation is based on the condition stipulating that elementary patterns in both the coordinate systems are similar. Straight lines in one coordinate system are represented in the other as generally curved with a disrupted dividing ratio, but the angles between their images remain preserved. This method's disadvantage is ambiguous results on the borders of transformed areas and therefore, the method is not much suitable to convert points from a larger area [14]. This third-order transformation was applied to create the 1952 Coordinate System (S-52).

\section{Transformation of system coordinates through a multiple regression analysis}

According to [12], the Helmert transformation has a linear character. By means of its parameters, it is not possible to capture local inhomogeneity of a reference triangulation network well. The inhomogeneity of local triangulation networks can be reduced by means of multiple regression relations being used for the transformation.

The transformation can be described by means of the following multiple regression relations: 


$$
\begin{aligned}
& \Delta B=A_{0,0}+A_{1,0} U+A_{0,1} V+A_{2,0} U^{2}+A_{0,2} V^{2}+A_{1,1} U V+\ldots=\sum_{p, q} A_{p, q} U^{p} V^{q}, \\
& \Delta L=B_{0,0}+B_{1,0} U+B_{0,1} V+B_{2,0} U^{2}+B_{0,2} V^{2}+B_{1,1} U V+\ldots=\sum_{p, q} B_{p, q} U^{p} V^{q}, \\
& \Delta H=C_{0,0}+C_{1,0} U+C_{0,1} V+C_{2,0} U^{2}+C_{0,2} V^{2}+C_{1,1} U V+\ldots=\sum_{p, q} C_{p, q} U^{p} V^{q},
\end{aligned}
$$

where $p, q=0,1,2, \ldots, U=k\left(B-B_{0}\right)$ is normalized geodetic latitude. $V=k\left(L-L_{0}\right)$ is the normalized geodetic longitude, $\mathrm{k}$ is a scale factor and $\mathrm{B}_{0}, \mathrm{~L}_{0}$ are geographical coordinates of a transformed area centre.

The author [12] states that the multiple regression transformation is more than four times more effective than the Helmert transformation into EUREF89 and as much as six times more effective in case of a transformation of S-42/83 to EUREF89.

$\underline{\text { Transformation of system coordinates by means of non-linearized rotation matrices and conformal }}$ projection

In [10], a method of transformation from WGS-84 geodetic datum coordinates into a local coordinate system is processed by means of non-linearized rotation matrices to ensure millimetre transformation accuracy resulting in high accuracy of point position determination using the NAVSTAR GPS technology. The method has several advantages. Through the transformation, high relative accuracy of point position determination using the GNSS technology is preserved, and next, the local system is implemented so that no complex relations are needed to reduce the measured parameters. Compared to a similarity transformation, instead of surveying in three identical points, one is sufficient.

The mathematical formulation of a coordinate transformation from a geocentric system to a local geocentric system by means of rotation matrices and a conformal projection [11] making use of $\mathrm{P}$ surface, osculating sphere and its subsequent transformation into the local system retains a high accuracy of determining coordinates using the GNSS technology. It does not distort angles or produce scale errors. In addition, it minimizes network point relative heights from the basic plane as a result of which distance reductions from relative height above sea level are mostly negligible. This also ensures sufficient compliance of the local planar system with S-JTSK by means of one identical point.

\section{Non-linear 3D transformations}

It is apparent from the results in [24] that the lowest positional deviation is reached by a general quadratic transformation and it is stated that the most suitable transformations between the geocentric coordinate system and S-JTSK are non-linear transformations. According to [9], the model of a local 3D non-linear transformation overcomes the problem of correlation between estimated parameters, which occurs during global non-linear transformations, and is suitable for small areas too.

Other possibilities of transformation, e.g., by means of robust methods are stated e.g. in [8], [17].

\section{DIRECT TRANSFORMATION BETWEEN S-JTSK AND ETRS89 SYSTEMS}

The direct transformation between the S-SK (St. Stephen) and ETRS89 systems has been implemented in Brno and its environs. A set condition was to start from the points of a geodetic base, and thus for the St. Stephen Datum, cadastral triangulation points (1822-1829) of order I-III within Brno were used, in case of which it was possible to document their origin and accuracy. The original point coordinates of the Stable Cadastre system, St. Stephen, in Brno, were obtained from archive materials of UAZK, in particular from protocols of triangulation calculations (1822-1827). After carrying out terrain reconnaissance and identity analysis [21], 8 points were identified, suitable for surveying using the GNSS technology.

As the reference station for point surveying using the GNSS technology, the south-west pillar on the roof of the Faculty of Civil Engineering (BUT) in Brno, was selected. This pillar was labelled under a working title of TUBO_JZ. The TUBO_JZ coordinates in ETRS89 were determined during earlier measurements $\left(\varphi=49^{\circ} 12^{\prime} 20,92837^{\prime \prime}, \lambda=16^{\circ} 35^{\prime} 34,25047^{\prime \prime}, \mathrm{H}=322,563 \mathrm{~m}\right)$. For measuring, 3 two-frequency apparatuses were used, and the mean time of measuring in individual points was about an hour. The following parameters were selected for calculations: 
- Cut of angle:

- Ephemeris:

- Tropospheric model:

- Ionospheric model:

- Maximum baseline length :

- Processing mode: $10^{\circ}$,

Broadcast,

Saastamoinen,

Standard,

$20 \mathrm{~km}$,

all baseline.

Tab.1 Resulting geographical coordinates of points in the ETRS89 system

\begin{tabular}{|c|c|c|c|c|c|c|c|c|}
\hline Point Id & Point Class & Epochs & Latitude & Longitude & Elip.Hgt. & S.d.Lat. & S.d.Lon. & S.d.H. \\
\hline 944210024 & Measured & $09 / 20 / 200306: 48: 50$ & $49^{\circ} 14^{\prime} 06.86054^{\prime \prime} \mathrm{N}$ & $16^{\circ} 36^{\prime} 01.22831^{\prime \prime} \mathrm{E}$ & 344,2271 & 0.0002 & 0.0001 & 0.0003 \\
\hline 944230014 & Measured & $09 / 20 / 200309: 50: 20$ & $49^{\circ} 05^{\prime} 18.45970^{\prime \prime} \mathrm{N}$ & $16^{\circ} 42^{\prime} 31.66072^{\prime \prime} \mathrm{E}$ & 261,5801 & 0.0006 & 0.0004 & 0.0010 \\
\hline 943070030 & Measured & $09 / 20 / 200310: 06: 50$ & $49^{\circ} 06^{\prime} 58.22828^{\prime \prime} \mathrm{N}$ & $16^{\circ} 25^{\prime} 36.28757^{\prime \prime} \mathrm{E}$ & 495.4455 & 0.0015 & 0.0009 & 0.0023 \\
\hline 944170014 & Measured & $09 / 20 / 200307: 10: 20$ & $49^{\circ} 10^{\prime} 50.90132^{\prime \prime} \mathrm{N}$ & $16^{\circ} 47^{\prime} 01.74861^{\prime \prime} \mathrm{E}$ & 324,4055 & 0.0016 & 0.0009 & 0.0025 \\
\hline 944220029 & Averaged & $09 / 20 / 200308: 41: 00$ & $49^{\circ} 07^{\prime} 54.44743^{\prime \prime} \mathrm{N}$ & $16^{\circ} 39^{\prime} 50.49924^{\prime \prime} \mathrm{E}$ & 271.7589 & 0.0005 & 0.0003 & 0.0006 \\
\hline $943030010 *$ & Averaged & $09 / 20 / 200311: 32: 30$ & $49^{\circ} 05^{\prime} 22.01223^{\prime \prime} \mathrm{N}$ & $16^{\circ} 32^{\prime} 02.93827^{\prime \prime} \mathrm{E}$ & 305,9306 & 0.0007 & 0.0004 & 0.0006 \\
\hline 944230028 & Reference & $09 / 20 / 200311: 32: 30$ & $49^{\circ} 02^{\prime} 30.40543 " \mathrm{~N}$ & $16^{\circ} 38^{\prime} 20.76636^{\prime \prime} \mathrm{E}$ & 398,9631 & 0.0044 & 0.0009 & 0.0011 \\
\hline 943020011 & Reference & $09 / 20 / 200308: 41: 00$ & $49^{\circ} 10^{\prime} 41.07452^{\prime \prime} \mathrm{N}$ & $16^{\circ} 34^{\prime} 54.54647^{\prime \prime} \mathrm{E}$ & 356,3670 & 0.0006 & 0.0002 & 0.0021 \\
\hline TUBO_JZ & Control & $09 / 20 / 200314: 14: 50$ & $49^{\circ} 12^{\prime} 20.92837^{\prime \prime} \mathrm{N}$ & $16^{\circ} 35^{\prime} 34.25047^{\prime \prime} \mathrm{E}$ & 322,1563 & 0.0000 & 0.0000 & 0.0000 \\
\hline & & & & & & & & \\
\hline S.d.Lat. & Standard Deviation Latitude & & & & & & & \\
\hline S.d.Lon. & Standard Deviation Longitude & & & & & & \\
\hline S.d.H. & Standard Deviation Height & & & & & & \\
\hline
\end{tabular}

The information on the course of calculation, or the computational record, including the resulting coordinates, variance-covariance matrices and other accuracy characteristics are available in [21].

The transformation was implemented using the software by Leica SKI-Pro, where an ellipsoid used for the St. Stephen Datum was defined, and the origin of the coordinate system (St. Stephen) in geographic coordinates was selected.

The applied software offers several types of transformations:

- Classical $3 D$ is a classical spatial transformation according to the Bursa-Wolf method or MolodenskyBadekas method,

- Interpolation is a method that inserts the measured coordinates among the coordinates of a given system, i.e. their position and height independently from each other. Errors in heights are not projected into positions, and neither ellipsoid nor map projection must be known. There is no necessity to identify points for positional or height adjustments. The method is suitable for transformations within small areas $\left(10-15 \mathrm{~km}^{2}\right)$.

- OneStep transforms positions and heights separately. Positions are transformed individually through a classical 2D transformation.

- TwoStep is a method of split transformations of position and height. Positions are determined by a 3D transformation; heights are calculated separately.

For direct transformations between the SK and ETRS89 systems, the Interpolation and OneStep transformations were chosen, due to the separate transformations of position and height. Then, transformation keys and residual values of $\mathrm{dX}$ and $\mathrm{dY}$ were calculated, for the Interpolation transformation see Tab.2, and for the OneStep transformation see Tab.3. 
Tab. 2 Table of residual values of Interpolation transformation

\begin{tabular}{|c|c|c|c|c|}
\hline \multicolumn{5}{|c|}{ Interpolation transformation } \\
\hline A system & B system & $d X[\mathrm{~m}]$ & $d Y[m]$ & Position $[\mathrm{m}]$ \\
\hline 944230028 & 944230028 & -0.190 & 0.048 & 0.196 \\
\hline 943010023 & 943010023 & -0.044 & 0.042 & 0.061 \\
\hline 943020011 & 943020011 & -0.088 & -0.082 & 0.120 \\
\hline 943070030 & 943070030 & 0.058 & -0.012 & 0.059 \\
\hline 944170014 & 944170014 & -0.093 & -0.005 & 0.093 \\
\hline 944210024 & 944210024 & 0.129 & 0.004 & 0.129 \\
\hline 944220029 & 944220029 & -0.150 & 0.085 & 0.172 \\
\hline 944230014 & 944230014 & 0.377 & -0.079 & 0.386 \\
\hline
\end{tabular}

Tab. 3 Table of residual values of OneStep transformation

\begin{tabular}{|c|c|c|c|c|}
\hline \multicolumn{5}{|c|}{ OneStep transformation } \\
\hline A system & B system & $d X[\mathrm{~m}]$ & $d \mathrm{Y}[\mathrm{m}]$ & Position $[\mathrm{m}]$ \\
\hline 944230028 & 944230028 & -0.308 & 0.251 & -0.398 \\
\hline 943010023 & 943010023 & 0.044 & -0.014 & -0.046 \\
\hline 943020011 & 943020011 & -0.152 & -0.121 & -0.194 \\
\hline 943070030 & 943070030 & 0.262 & 0.004 & -0.262 \\
\hline 944170014 & 944170014 & -0.214 & -0.131 & -0.250 \\
\hline 944210024 & 944210024 & 0.146 & -0.049 & -0.154 \\
\hline 944220029 & 944220029 & -0.226 & 0.089 & -0.243 \\
\hline 944230014 & 944230014 & 0.448 & -0.029 & -0.449 \\
\hline
\end{tabular}

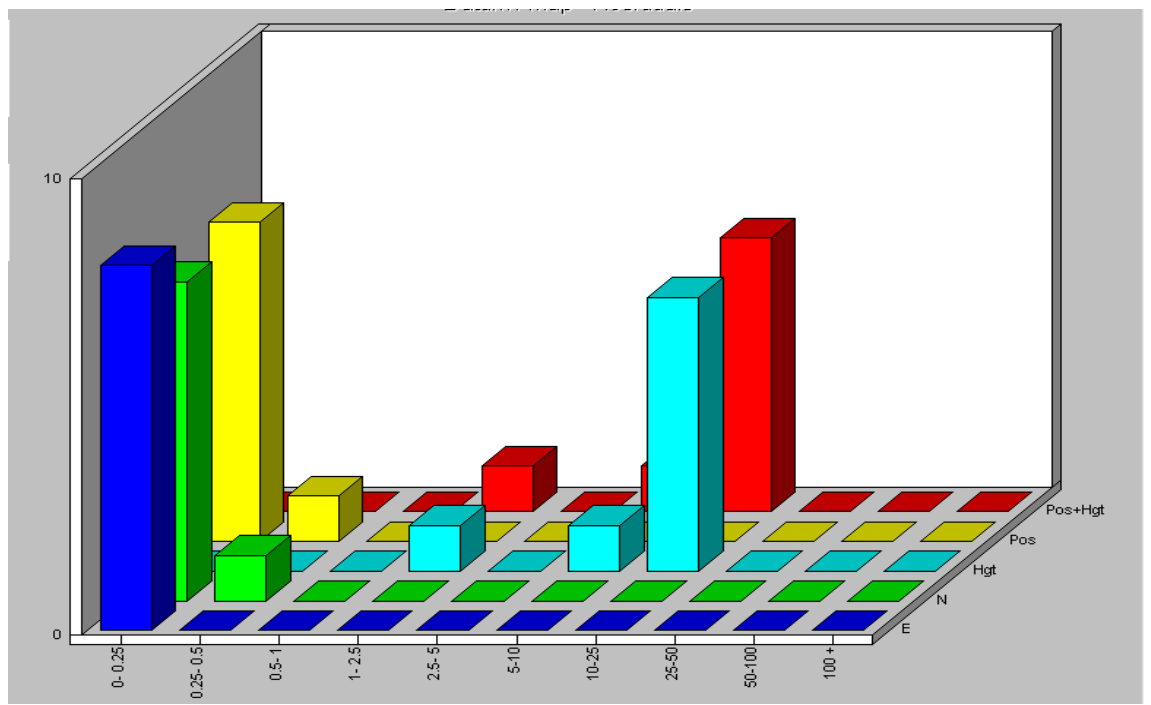

Graph 1: Residual values of Interpolation transformation 


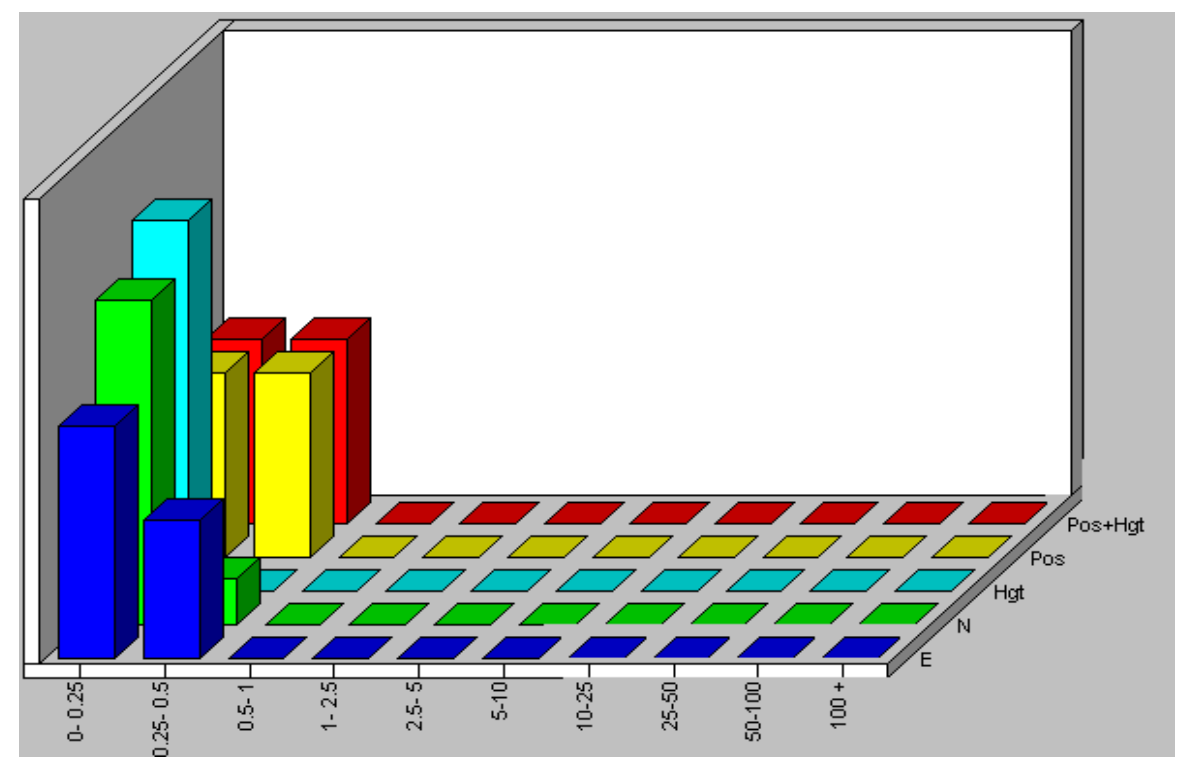

Graph 2: Residual values of Onestep transformation

Values of transformation parameters:
System A: GPS 0903
System B: Brno St. Stephen
Ellipsoid: $\quad$ WGS 1984
Zach $(S-S K)$
System: $\quad$ WGS84
St. Stephen

Transformation parameters of Interpolation transformation:

Position:

\begin{tabular}{rr}
0.00320050 & -0.99994511 \\
-0.99996042 & 0.00317242 \\
\hline
\end{tabular}

Scale:

$\mathrm{X}: \quad-49.7712 \mathrm{ppm}$

$\mathrm{Y}: \quad-34.5489 \mathrm{ppm}$

Translation:

$\mathrm{X}: \quad-18068.6773 \mathrm{~m}$

Y: $\quad-126005.1615 \mathrm{~m}$

Transformation accuracy: $\quad \mathrm{dX}: \quad 0.0554 \mathrm{~m}$

dY: $\quad 0.1729 \mathrm{~m}$

Mean scale between A and B: 0.99995507

Transformation parameters of OneStep Transformation:

2D_Helmert Transformation:

Number of common points: 8

Rotation origin: $\quad \mathrm{X}_{0}$ : $4.7903 \mathrm{~m}$

$\mathrm{Y}_{0}: \quad 0.7171 \mathrm{~m}$

\begin{tabular}{lcccc} 
No: & Parameter: & Value: & r.m.s. & Unit: \\
\hline 1 & Shift dX & -104849.7163 & 0.0799 & $\mathrm{~m}$ \\
2 & Shift dY & -18137.8178 & 0.0799 & $\mathrm{~m}$ \\
3 & Rotation about Z & 647341.81040 & 1.61955 & ${ }^{\prime}$ \\
4 & Scale & -45.8670 & 7.8521 & ppm
\end{tabular}




\section{CONCLUSIONS}

The reason for geo-referencing old and abandoned main mine workings and pits is the threat of landscape and health of population due to possible gas leaks from underground to the surface. An equally serious problem is the real possibility of mechanical damage to buildings due to break and fall through of backfill materials in case of construction and other activities in these areas.

In the process of disposing old main mine workings, a final report is being prepared whose integral part must be, among others, the passportization of mine workings open to the surface or close to the surface. Part of the passportization is the registration list of a main mine working, which in addition to a pit (adit) name must contain coordinates $x, y$ of the pit axis in a valid coordinate system in compliance with Decree of the Czech Mining Office (CBU) No. 435/1992 Coll., as amended. For purposes of the passportization, it is necessary to set out the mouth of all active and old main mine workings from the period of the oldest mining activities in the field. The position coordinates of the old main mine workings are determined via a graphical transformation of identical points of LC (Land Cadastre) and LR (Land Registry) maps or via a linear transformation to S-SK and then the Helmert Transformation to JTSK. After setting out and verifying the mouth position of a pit or adit in the terrain (by geophysical survey and drilling), the space on the surface is determined for safety reasons, in which the protruding mine atmosphere could endanger the life or health of persons, because the passportized main mine workings in the Ostrava part of OKC belongs among gassy coal mine workings with a possibility of methane exit to the surface.

During activities of liquidation and rehabilitation of old mine workings, the Otto Coordinate System, in which the positions of the main mine workings and pits had been identified, acquired its importance. Since the Otto Coordinate System is linearly linked to the Stephen Datum of Cadastre Coordinates, the transfer between these systems is simple. With the development and application of the GNSS technology (Global Navigation Satellite System) the possibility of setting out positions of old main mine workings and pits by methods of the technology, was analyzed. For the purpose of setting out the main mine workings and pits by the GNSS technology, an experiment was carried out, leading to creating a transformation key of a direct transformation between the St. Stephen Datum of Cadastre Coordinates and ETRS89.

A set of points of the St. Stephen Datum of Cadastre Coordinates, triangulation networks of the order I-III from the original adjustment was selected. From this set, 36 points were selected, which might be regarded as identical ones. After the reconnaissance of all 36 points, only 8 of them were selected, which satisfied the conditions for surveying using the GNSS technology. These points were then analysed for their identity with the St. Stephen Datum of Cadastre Coordinates. The points that were surveyed by the GNSS technology acquired their coordinates in the spatial European Terrestrial Reference System (ETRS89).

Two transformation methods were used for direct transformations between the SK and ETRS-89 systems,

- OneStep transformation, and

- Interpolation transformation.

Both the transformations solve the key of transformation as separate tasks for positions and heights. The transformations were solved by means of the Leica SKI-Pro software, where an ellipsoid for the SK system had been defined and St. Stephen Datum origin coordinates had been inserted in geographic coordinates. For both the transformations, transformation keys and residual values of $\mathrm{dX}$ and $\mathrm{dY}$ were calculated. As expected, lower residual values were shown in case of the Interpolation transformation.

\section{REFERENCES}

[1] ČADA, V.: Obnova katastrálního operátu v lokalitách souřadnicových systémů stabilního katastru, Geodetický a kartografický obzor, roč.45/87, 1999, číslo 6, str.122, ISSN 0016-7096

[2] ČADA, V.: Robustní formy tvorby a vedení digitálních katastrálních map v lokalitách sáhových měřitek, Habilitační práce podaná na ČVUT Praha v oboru Geodézie a kartografie, Plzeň, 2003

[3] BÖHM, J.: Vyšší geodézie II, Souřadnicové soustavy, SNTL, Praha 1966

[4] BÖHM, J.: Matematická kartografie, díl II., Souřadnicové soustavy v geodézii a kartografii, Donátův fond, rektorát Vysoké školy technické Dr. E.Beneše v Brně, Brno 1951

[5] BÖHM, J., HORA, L., KOLENATÝ, E: Vyšší geodézie, díl I, II, Praha 1982, 1983

[6] BUČKO, E.: Princip a technológia merani GPS, Zborník prednášok Katedry geodézie Stavebnej fakulty STU Bratislava, 18.zošit, október 1996 
[8] GAŠINCOVÁ, S., GAŠINEC, J., TREMBECZKÁ, E.: Vyrovnanie 2D geodetických sietí pomocou robustných metod (Adjustment of 2D geodetic networks by robust estimations) - 2008. In: Geodézia, kartografia a geografické informačné systémy 2008. - Košice : GK a GIS, 200817 s. - ISBN 9788055300795

[9] HEFTY, J., FROHMAN, E.: Nelineárne trojrozmerné transformácie a ich využitie na prevod súradníc medzi S-JTSK a ETRS-89, Geodetický a kartografický obzor, roč. 44/86, 1998, č.6, pp.121-127, ISSN 0016-7096

[10] MELICHER, J., FLASSIK, T.: Transformácia súradníc zo Svetového geodetického systému do lokálneho súradnicového systému pomocou nelinearizovaných rotačných matíc, GaKo 44/86, č. 2, ISSN 0016-7096

[11] MELICHER, J., GALGONOVÁ, R.: Transformácia súradnic z geocentrického rovníkového systému do lokálneho rovinného systému pomocou rotačných matic a konformného zobrazenia, Geodetický a kartografický obzor, roč. 45/87, 1999, č. 2, pp. 25-29, ISSN 0016-7096

[12] MOJZEŠ, M.: Transformácia súradníc systémov multiregresnou analýzou, Kartografické listy, 1995, č. 5

[13] NEVOSÁD, Z.: K identitě bodů při spojování družicových a triangulačních sítí, sborník referátů Seminář s mezinárodní účastí Zkušenosti s využitím GPS pro bodová pole, VUT FAST Brno, 1998

[14] NEVOSÁD, Z:: Geodézie IV, Vyrovnání geodetických sítí, Vojenská akademie Brno 1994

[15] KOSTELECKÝ, J.: K převodu výsledků měření aparaturami GPS do souřadnicového systému S-JTSK, Geodetický a kartografický obzor, 39/1993 č.7, ISSN 0016-7096

[16] KOSTELECKÝ, J., CIMBÁLNÍK, M.: Převod souřadnic mezi S-JTSK a ETRS-89, Geodetický a kartografický obzor, ročník 42/84, č. 2,1996, PP.23-32, ISSN 0016-7096

[17] LABANT, S., WEISS, G., KUKUČKA, P.: Adjustment of a geodetic Network Measured by a Satellite Technology in the Dargovskych Hrdinov Suburb, Acta Montanistica Slovaca, Volume 16, Issue 3, 2011, pp. 229-237, ISSN 1335-1778

[18] OLŠOVSKÝ, V.: Analýza možnosti využití obecné transformace pro transformaci elipsoidických souřadnic a výpočtu relativních odlehlostí elipsoidů, kandidátská disertační práce

[19] PROVÁZEK, J.: Vývoj polohových základů na území ČR, Zeměměřický úřad, Praha, 2000

[20] RYŠAVÝ, J.: Geodesie, SNTL Praha 1955

[21] STAŇKOVÁ, H.: Problematika identity trigonometrických bodů pro účely mezisystémových transformací v Brně a okolí, Disertační práce, Brno: VUT FAST, 2006

[22] STAŇKOVÁ, H.. ČERNOTA, P.: A Principle of Forming and Developing Geodetic Bases in the Czech Republic, Geodesy and Cartography, Vilnius: Technica, 2010, Vol.36, No.3 p. 103-112, ISSN 1392-1541 print/ISSN 1648-3502 online

[23] ŠESTÁK, L.: Možnosti použití splajnů pro transformaci souřadnic, Písemná práce k rigorózní zkoušce, Vojenská akademie Brno 1998

[24] VALKO, J., DEMČÁKOVÁ, L.: Transformácia súradníc medzi geocentrickým súradnicovým systémom a S-JTSK, Kartografické listy, 1998, č. 6

\section{RESUMÉ}

Georeferencování, jinými slovy vyjádření prostorových referencí, je proces určení vztahu mezi polohou dat v př́strojovém souřadnicovém systému a geografickou, resp. mapovou polohou. Transformace souřadnic je převod souřadnic bodů $\mathrm{z}$ jednoho souřadnicového systému do druhého. Proces převodu souřadnic je řešen pomocí exaktně vyjádřených transformačních rovnic a následným výpočtem transformačního klíče. Transformací jsou hledány optimální vztahy mezi dvěmi souřadnicovými systémy. Starým dủlním dílem se rozumí opuštěné důlní dílo v podzemí nebo opuštěný lom po těžbě vyhrazených nerostů. V obou případech není znám původní provozovatel ani jeho nástupce. Registr starých důlních děl je Ministerstvem životního prostředí pověřena vést Česká geologická služba - Geofond. Proces transformace mezi dvěmi rovinnými souřadnicovými systémy a následně i prostorovým systémem a určením optimální vztahů mezi nimi je jedním z výsledků předloženého článku. Součástí je rovněž experiment o př́ímou transformaci mezi rovinným katastrálním souřadnicovým systémem svatoštěpánským a prostorovým systémem ETRS89, který mohl být proveden až po definování základních a charakteristických vlastností jednotlivých zobrazení, tzn. použitého elipsoidu a typu zobrazení. 